\title{
RECENT RECESSION AND THINNING OF OKPILAK GLACIER, NORTHEASTERN ALASKA*
}

\author{
Edward G. Sable $\dagger$
}

\section{Introduction}

The presence and general extent of a very recent glacial advance in northern Alaska have been known for several years, although little information on the time or duration of this advance has been obtained. The writer, doing bedrock mapping in northeastern Alaska in 1957-1958, was fortunate in being able to examine briefly perhaps the only locality in northern Alaska where observations and photographs of a moderate-sized subpolar glacier had been taken as long as half a century ago. This valley glacier, the Okpilak Glacier, lies in the Romanzof Mountains, northeastern Brooks Range.

The Romanzof Mountains, the highest mountain group in the Brooks Range, contain the most extensive system of valley glaciers in northern Alaska. About 600 square miles in area, the highest parts of the mountains lie between the Hulahula and Jago rivers. The central part of the mountains is deeply cut by the Okpilak River and its tributaries (Fig. 1). Altitudes of the higher peaks are about 9000 feet, and relief is as much as 7000 feet. Numerous valley glaciers as much as 5.5 miles long are estimated to cover collectively about 100 square miles; most of these are on the north side of the divide and flow in northerly directions. One of the largest is the Okpilak Glacier, which feeds the west fork of the Okpilak River. Comparisons between observations made in 1907 and 1958 show that at least the lower part of this glacier has wasted appreciably, and suggest that its latest advance may have taken place in recent historic time.

\section{Investigations and sources}

The first geological reconnaissance along the Okpilak River valley was made by Ernest de K. Leffingwell, who ascended to within 3.5 miles of the head of Okpilak Glacier in June 1907. His report includes a general description and several photographs of the glacier (Leffingwell 1919, p. 156-157, Pl. XVIII, XIX, XX). In addition, several unpublished photographs taken by Leffingwell in this vicinity were obtained by the writer from the U. S. Geological Survey.

* Publication authorized by the Director of the U. S. Geological Survey.

$\dagger$ U. S. Geological Survey, Elizabethtown, Kentucky. 
Field investigations by the writer in the Romanzof Mountains during the summers of 1957 and 1958 included one day spent in the vicinity of Okpilak Glacier. Photographs and observations on August 21, 1958 include some taken at or near Leffingwell's points of observation.

Aerial photography covering the vicinity of Okpilak Glacier includes Trimetrogon photographs taken at about 12,000 feet by the U. S. Air Force on July 16, 1947; low-altitude photographs taken by the U. S. Navy on August 20 and 27, 1950; and twin low-oblique transverse photographs at a scale of approximately 1:63,360 taken for the U. S. Geological Survey on August 7 and September 5, 1956. An unpublished topographic map at a scale of $1: 63,360$ prepared by the U. S. Geological Survey was also used in making measurements not obtained during field work. Other work on Pleistocene and Recent glaciation in the Romanzof Mountains has been done by Kunkle (1958) and Keeler (1959).

The writer's field work in 1957-8 was supported by the Arctic Institute of North America under contract with the Office of Naval Research, and by the U. S. Geological Survey. The studies were primarily of bedrock geology, and detailed observations of glacial phenomena and other surficial features were therefore not made. Although the observations given in this report are qualitatively valid, the measurements and estimates are not precise figures; the more critical ones, however, are given with probable limits of error. It is hoped that the information presented herein may help motivate interest in detailed quantitative studies of this and other glacial problems in the Romanzof Mountains.

Thanks are expressed to Dr. Richard G. Ray, U. S. Geological Survey, who rechecked altitude measurements made on the 1956 aerial photographs, and to Prof. Donald F. Eschman, University of Michigan, who critically read the manuscript.

\section{Okpilak Glacier}

Leffingwell's (1919, p. 156-157) description of the Okpilak Glacier was limited to about the lower 2 miles. To this can now be added data obtained from more recent maps, field observations, and aerial photographs, a pair of which is shown in Fig. 2. The glacier is about 5.4 miles long, of which the main ice tongue, 2500 feet in average width, makes up the lower 3 miles. The total area covered by ice is about 5 square miles. The glacier heads at 7400 feet altitude in two composite cirques whose snow and firn areas each cover about 1 square mile. The firn limit lies at about $6400 \pm 100$ feet altitude, and the terminus at about 4500 feet. The ice surface has an average slope of about 6 degrees and the slope of the lower 1.2 miles is about 5 degrees. The entire glacier appears to lie within an outcrop belt of the preMississippian Neruokpuk formation, composed mostly of schistose quartzite, slate, schist, and minor limestone.

Main areas of transverse crevassing occur below the cirques and 1.3 and 2.2 miles above the terminus, where the glacier surface steepens in 


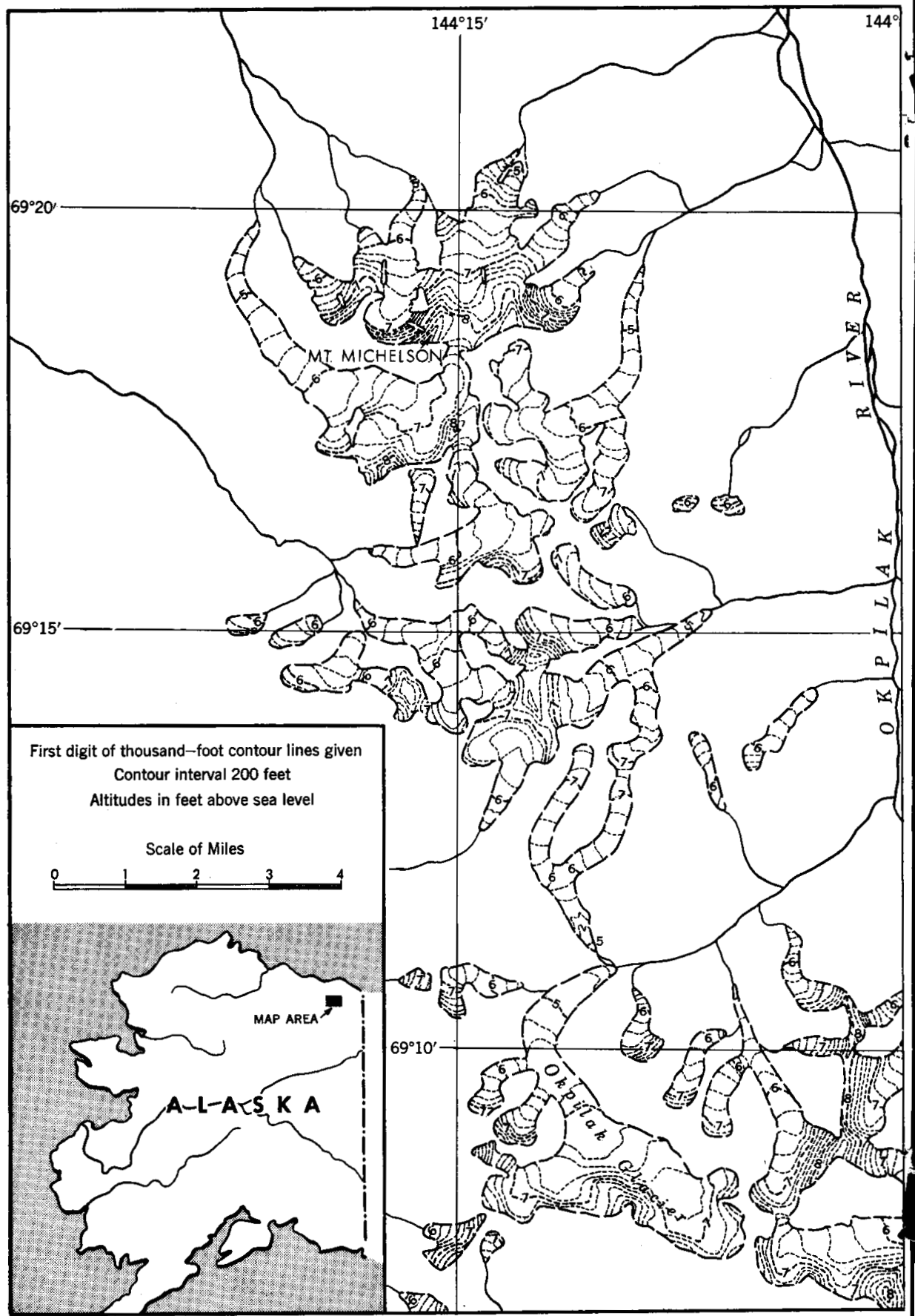

Fig. 1. Map showing distribution of present glaciers in northern 


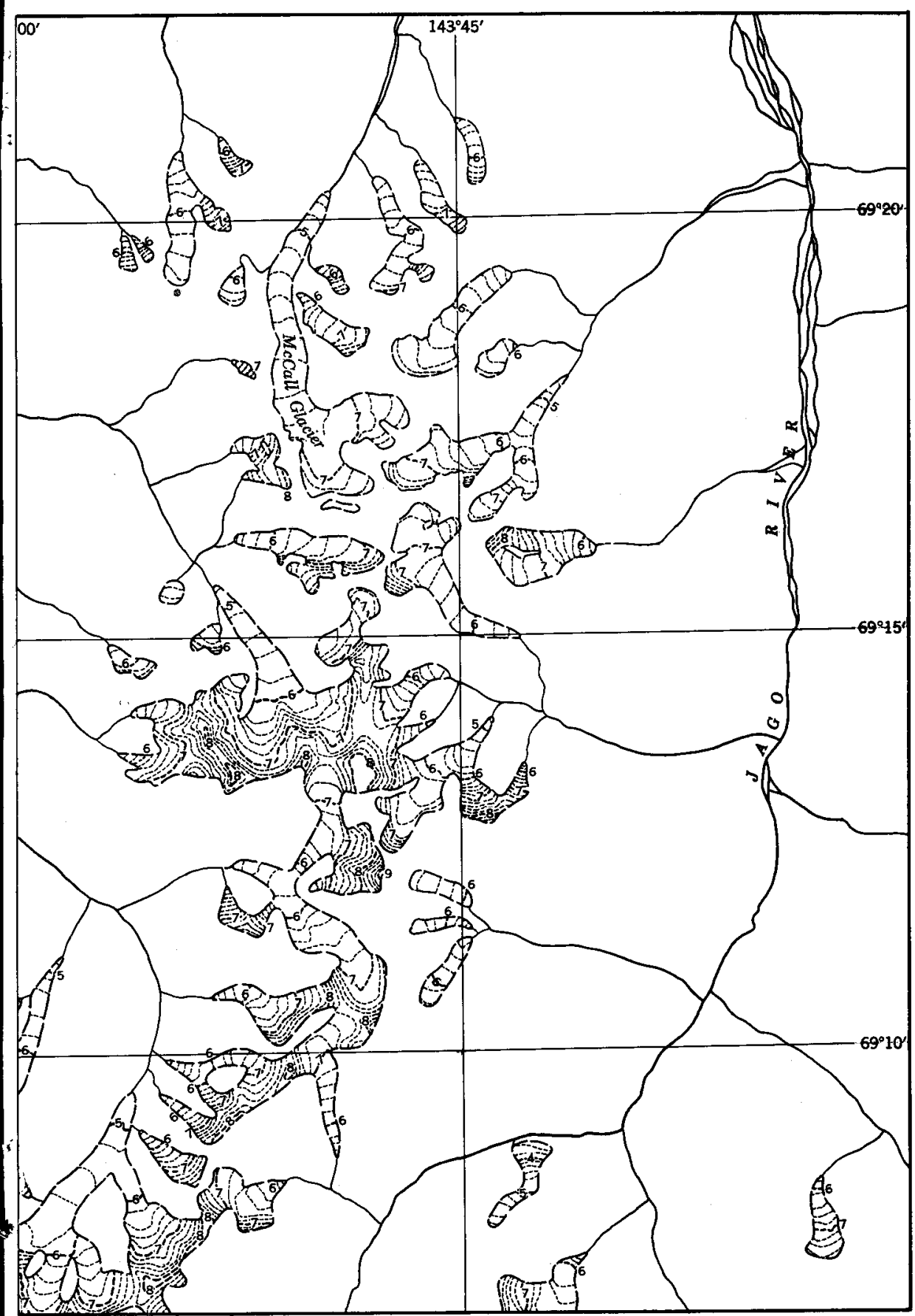

and central parts of Romanzof Mountains, northeastern Alaska. 


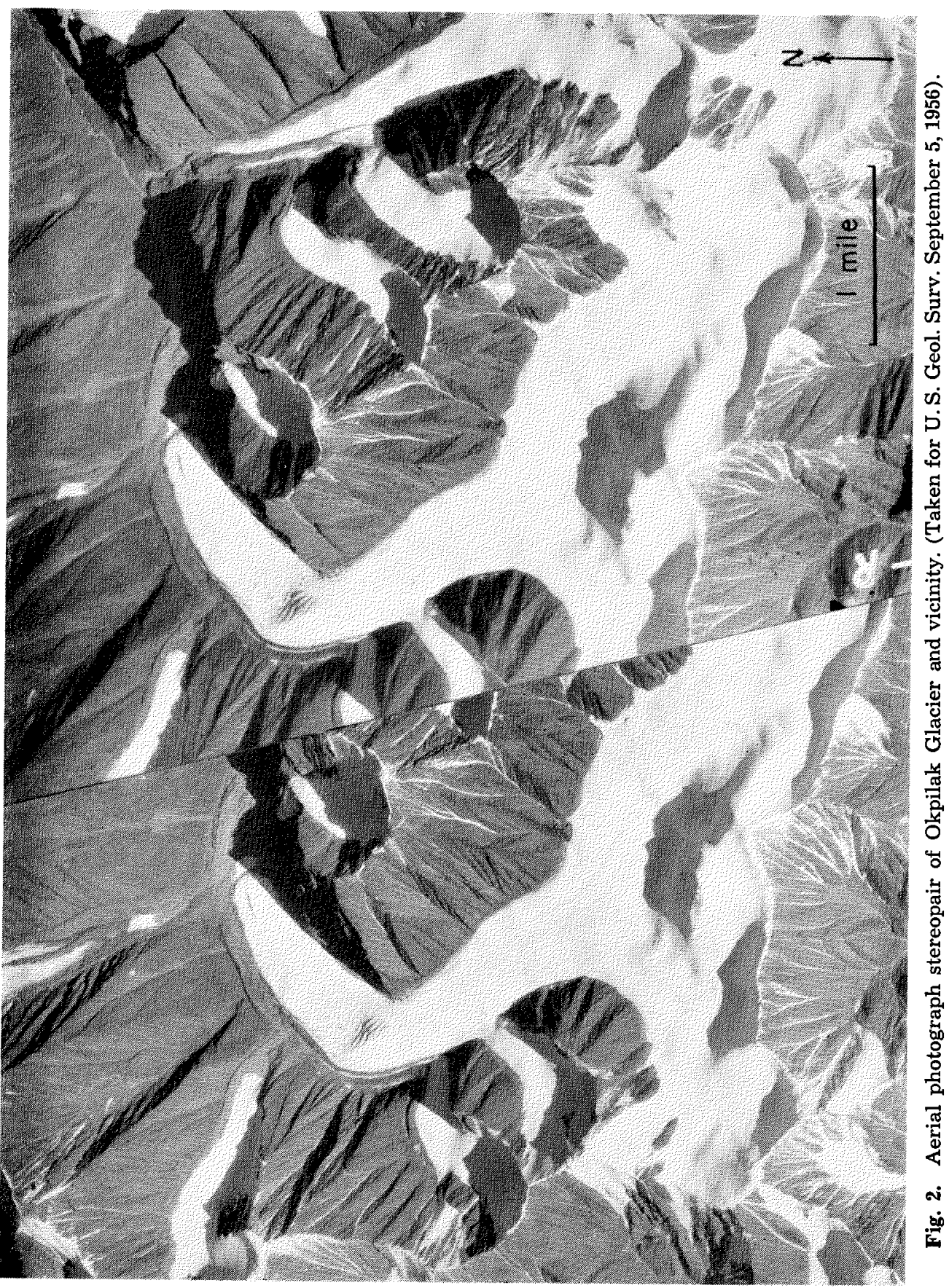


step-like form. The crevassed area 1.3 miles above the terminus was of the order of an ice fall in 1958. Smaller marginal crevasses are common. The transverse crevasses were observed by Leffingwell in 1907, but have probably become more prominent since that time because of thinning of the glacier.

Two small tributary glaciers flow into the Okpilak Glacier from the west, and there are two hanging glaciers on that side. A hanging glacier occurs also on the east side just below the terminus of Okpilak Glacier. Two well-defined medial moraines extend from the junctions of the tributary glaciers, and others, less prominent, persist northward from their sources in the cirques almost to the terminus.

The lower part of the Okpilak Glacier was free of snow in August 1958. The terminus margin was largely covered by drift, but the cover appeared to be thinner and more patchy than in 1907. Lateral and terminal moraines were described by Leffingwell to be in contact with and merging into the glacier surface. His 1907 photograph (Fig. 3A) shows at least 3 small abandoned moraines in the area between the terminus and a point about 2000 feet downstream, and his general description implies that they were fresh in appearance, consisting mostly of ice thinly veneered with drift. Except for their position in respect to the terminus and minor modifications resulting from drainage changes and wasting of the glacier, the fresh appearance of these moraines seems to have changed little in 51 years. In 1958 they. were a mixture of materials ranging from clay to boulder-sized rubble without visible ice but with a hummocky surface and unstable slopes. Their maximum relief was estimated to be 75 feet.

Evidence for recent recession. Comparison of field photographs from 1907 and 1958 augmented by the study of aerial photographs and topographic maps show that the terminus of Okpilak Glacier has receded $1000 \pm 100$ feet in 51 years.

Leffingwell's 1907 photograph (Fig. 3A) and description of the terminus of Okpilak Glacier shows the ice to be in contact with and grading into the innermost of the abandoned recessional moraines. In 1958 the recessional moraines appeared to be little changed, but a nearly flat alluvium-covered area about 1000 feet long and 700 feet wide occupied the 1907 position of the terminal ice (Fig. 3B). A braided stream fed by meltwater flowed mostly from underneath the terminus of the glacier and crossed the flat. A small aufeis field of about 1800 square feet adjoined the northeast side of the terminus.

The mean rate of terminus recession between 1907 and 1958 is of the order of 20 feet per year. The lack of morainal material on the flat may indicate that the glacier has receded continuously during this time. No measurements on the rate of flow have been made on the Okpilak Glacier, but the rate of surface flow on the McCall Glacier, 10 miles to the northeast, was of the order of $20 \mathrm{~mm}$. per day from June to November 1957 (Sater 


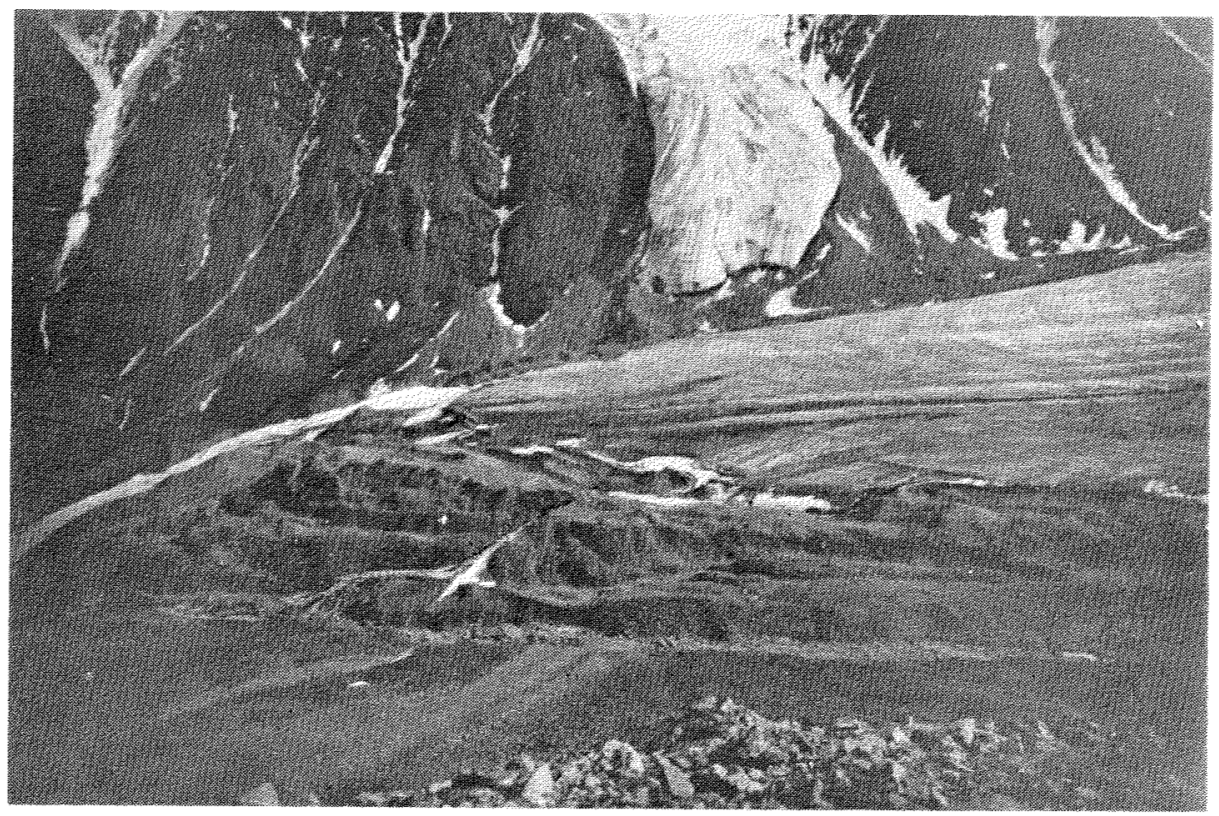

Fig. 3A. Terminus of Okpilak Glacier, June, 1907. (Looking southeast; U. S. Geol. Surv. photograph by E. de K. Leffingwell).

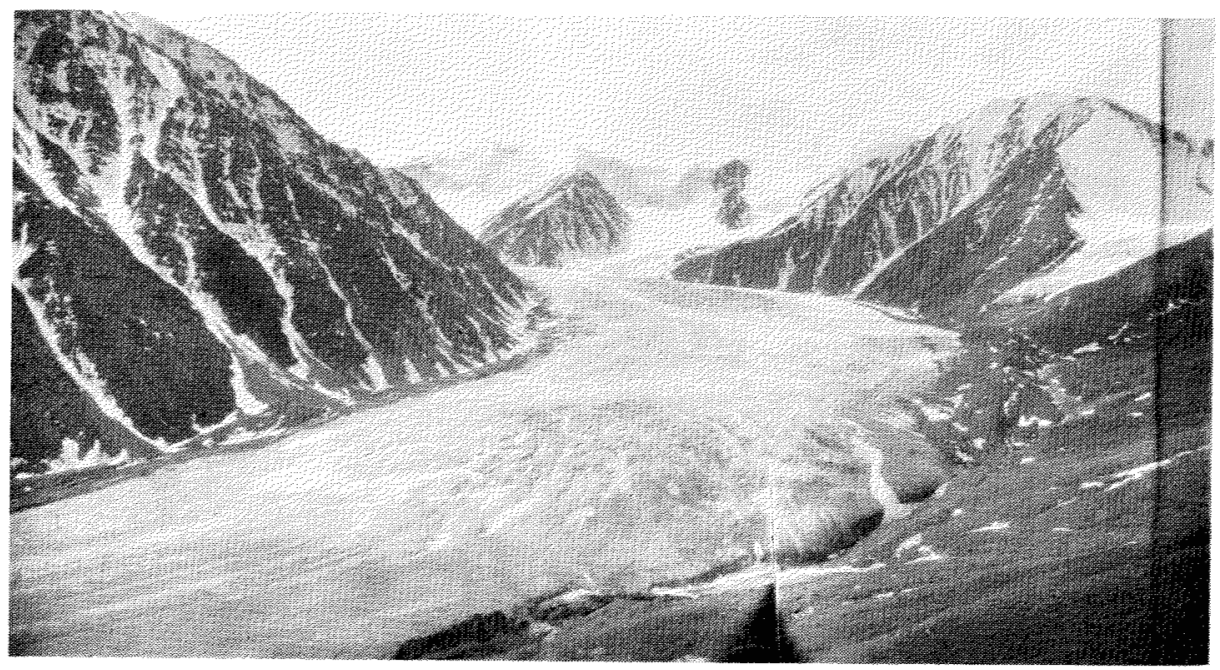

Fig. 4A. Lower part of Okpilak Glacier, June 1907. (Looking south; U. S. Geol. Surv. photograph by E. de K. Leffingwell). 


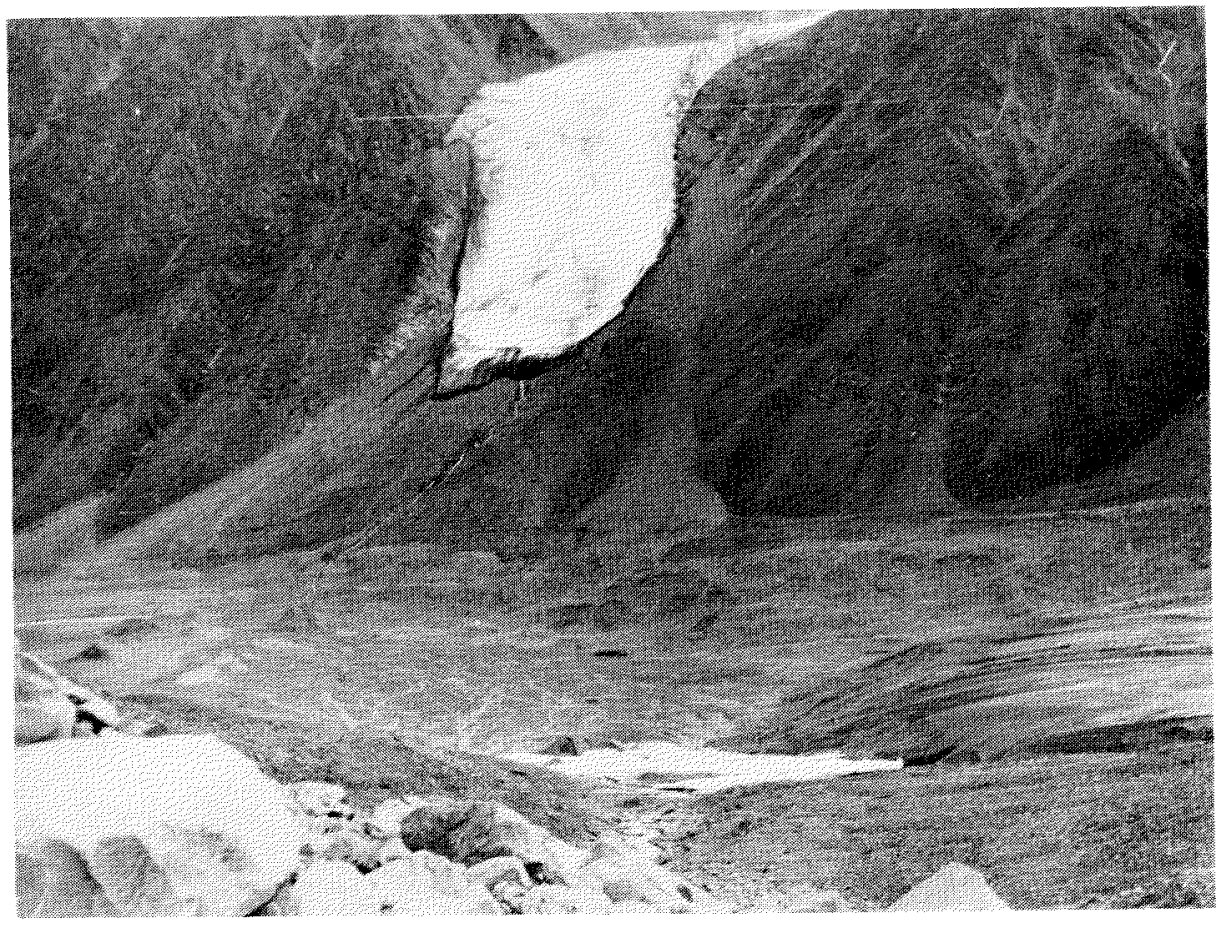

Fig. 3B. Terminus of Okpilak Glacier, August 21, 1958. Recessional moraines shown in Fig. 3A are beyond left margin of Fig. 3B.

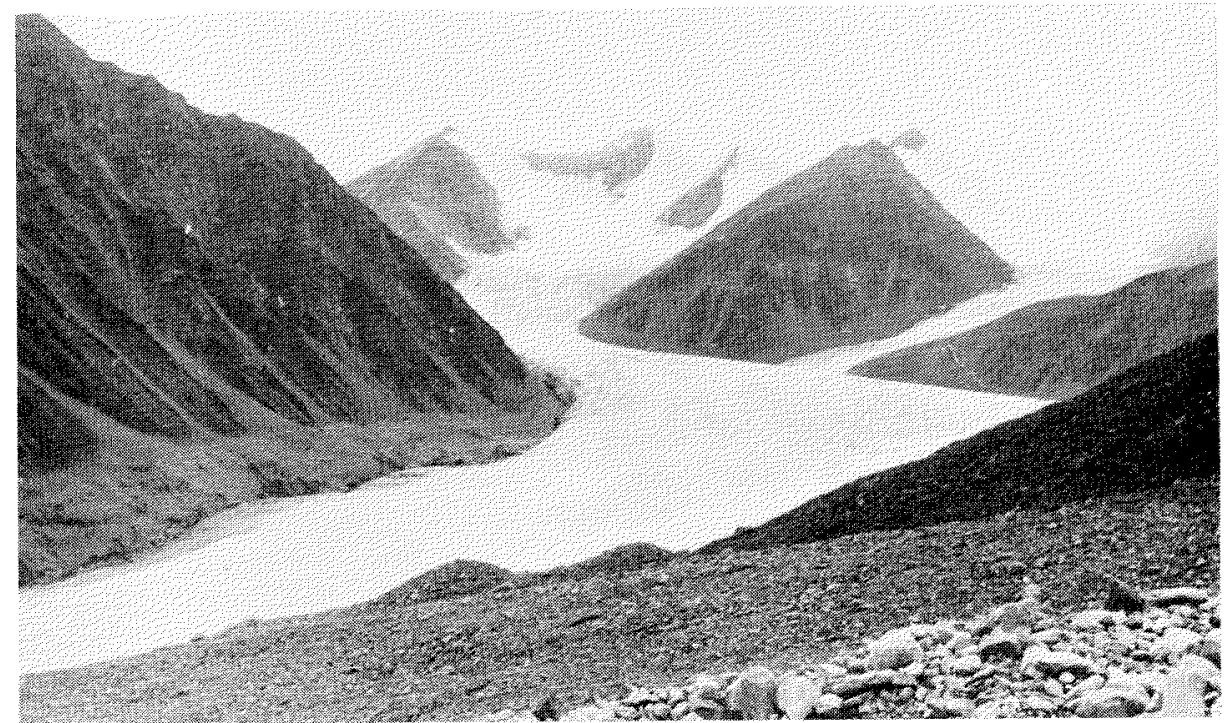

Fig. 4B. Lower part of Okpilak Glacier, August 21, 1958. 
1959, p. 86). If this figure is applied to the Okpilak Glacier, the mean rate of actual terminal melting rises to some 40 feet per year.

Evidence that a higher rate of recession has occurred recently is based on the comparison of aerial photographs taken in 1950 and 1956. Although the nature of the 1950 oblique photographs does not permit accurate quantitative comparison with the 1956 photographs, the change in position of the glacier terminus is noticeable, and the amount of recession between these dates is estimated at about 300 feet.

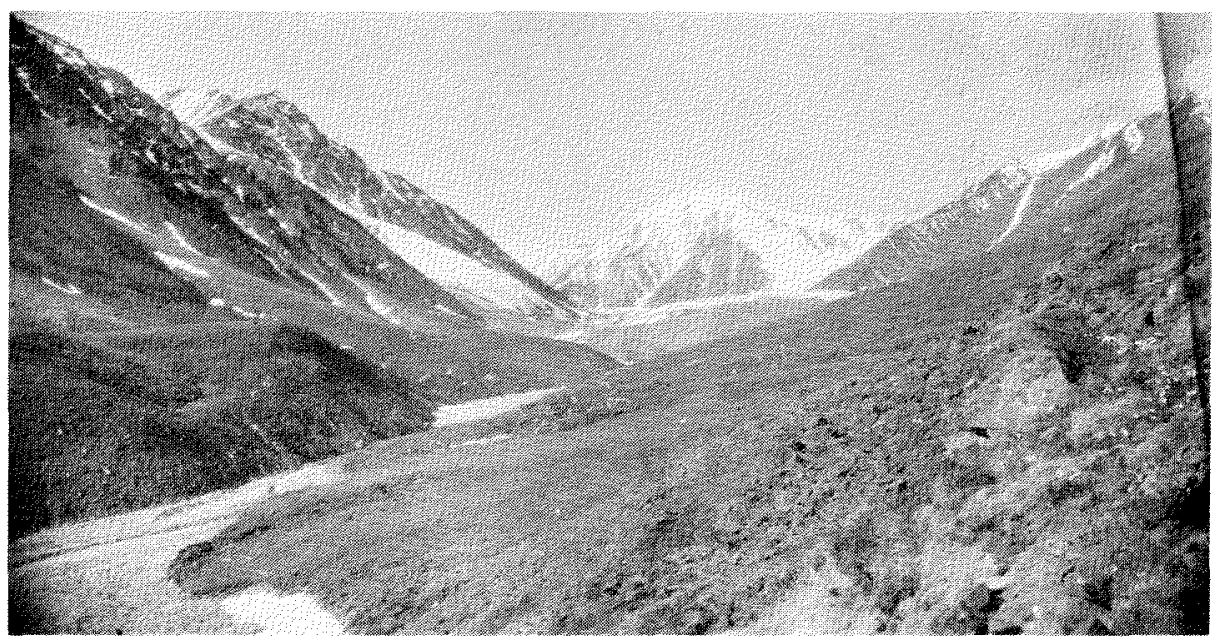

Fig. 5A. West fork of Okpilak River, June 1907. Lower end of Okpilak Glacier above recessional moraines of Fan Mountain glaciation in distance. (Looking southwest, U. S. Geol. Surv. photograph by E. de K. Leffingwell).

Evidence for recent thinning. Lowering of the ice surface in the lower part of Okpilak Glacier is evidenced by the relative positions of 1907 lateral moraines (Fig. 4A) and trim lines with respect to the 1958 ice surface (Fig. $4 \mathrm{~B})$. The eastern lateral moraines in 1907 were either level with or not more than 20 feet above the ice surface. Leffingwell (1919, p. 156) states that "the sides [of the glacier] as a rule grade into the lateral moraines or rest against the mountain sides. ..."

According to field estimates and measurements on aerial photographs along selected cross-sections in the lower 1.2 miles of the glacier, the crests of the lateral moraines in 1956-8 were $150 \pm 20$ to $210 \pm 20$ feet above the edges of the glacier, and roughly from 20 to 120 feet above the higher medial ice.

In Leffingwell's photograph (Fig. 5A) the terminal ice appears to be higher than the adjoining recessional moraines. In the 1958 photograph 
(Fig. 5B) taken from nearly the same location, the terminal ice is not visible, and field observations confirmed that the ice snout had melted to a gentle slope in accord with the general gradient of the glacier surface.

Most of the thinning has taken place in the lower one-third of the glacier, below the area of extensive crevassing, although thinning has also occurred above this area at least as far as the confluence of the two main

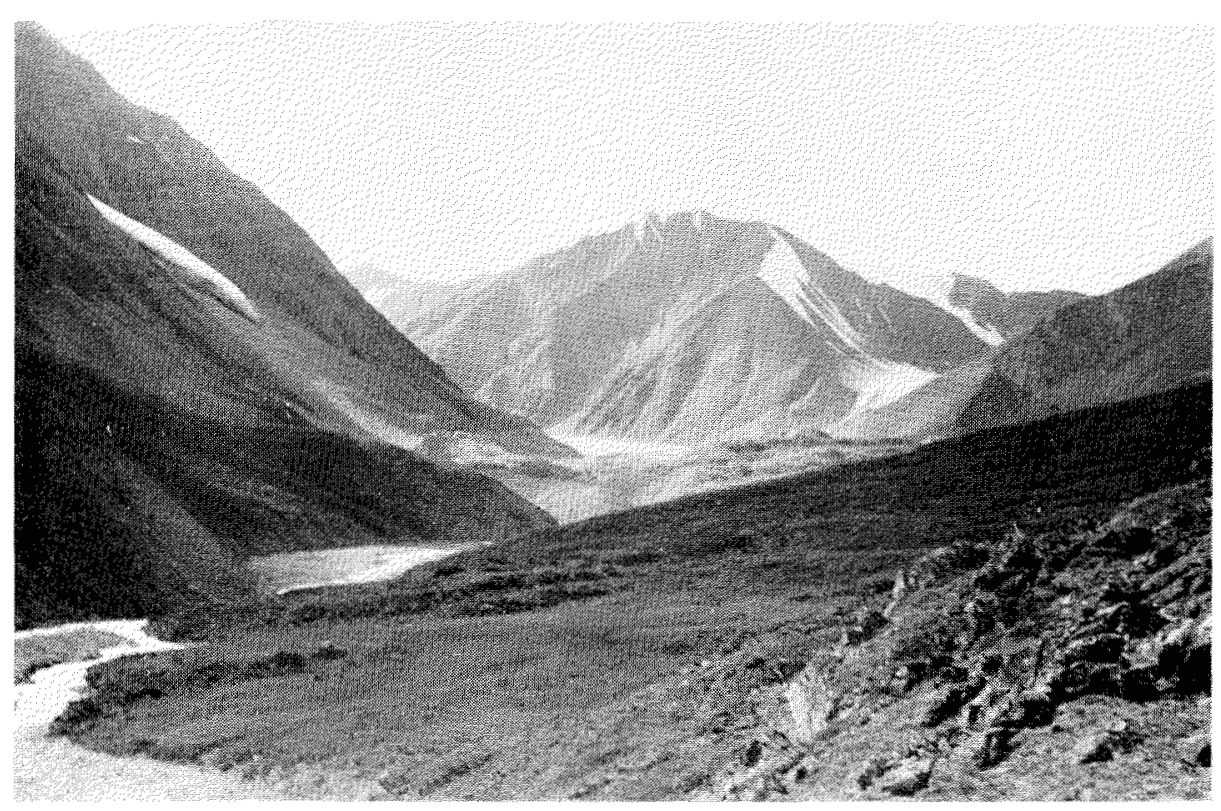

Fig. 5B. West fork of Okpilak River, August 21, 1958. Note thinning of Okpilak Glacier and recession of small hanging glacier at left shown by comparing with Fig. 5A.

cirques. The average amount of thinning in the lower 1.2 miles is estimated to be 150 feet, and the mean rate from 1907 to 1958 to be about 3 feet per year. As has been noted by many investigators of shrinking glaciers that terminate on land, the volume of ice lost due to thinning far exceeds the loss due to recession of the terminus. For the Okpilak Glacier, the ratio is roughly estimated to be at least 25:1.

\section{Tributary and hanging glaciers}

All the smaller glaciers in the vicinity of Okpilak Glacier, for which photographic information from 1907 and 1958 can be compared, show evidence of marked recent recession and thinning. The terminus of the small hanging glacier shown in Figs. 3A and 5A, which was about 60 feet from 
Okpilak Glacier in 1907, has retreated more than 300 feet (Figs. 3B and 5B). The tributary and hanging glaciers on the west side of Okpilak Glacier also show shrinkage effects by a diminution in width and thickness. Small hanging glaciers downstream from Okpilak Glacier have receded as much as several hundred feet.

\section{Correlation and conclusions}

Evidence for six Pleistocene and Recent ice advances along the Jago and Okpilak rivers has been discussed by Kunkle (1958), and five glacial advances along the McCall Creek valley, 10 miles northeast of Okpilak Glacier, have been recognized by Keeler (1959). These authors tentatively correlate the advances in the Romanzof Mountains with past glaciations on the Arctic Slope 60 to 270 miles to the west and southwest (Detterman 1953), (Detterman, Bowsher, and Dutro 1958). The most recent advance is the Fan Mountain glaciation (Detterman et al. 1958, p. 57), whose deposits are differentiated from older, more extensive ones largely on the basis of their fresh unweathered character and their proximity to present glaciers or recently evacuated cirques. Kunkle (1958) and Keeler (1959) use the above criteria, among others, as evidence for the most recent advance in their respective areas, and correlate it with the Fan Mountain glaciation. All writers concur that the Fan Mountain deposits are difficult to differentiate from those that are at present being formed, and that the advance was probably extremely recent and short-lived.

The recessional and end moraines within 1000 to 3000 feet from the 1958 terminus of Okpilak Glacier are considered to be deposits of the Fan Mountain advance. In 1958 all this material appeared to be free of vegetation, unweathered, and to have unstable slopes. The outermost end moraine is interpreted to represent the oldest Fan Mountain moraine of the Okpilak Glacier. The absolute age of these pre-1907 moraines is unknown, and although Leffingwell's observations imply that shrinkage of the Okpilak Glacier had already taken place before 1907 , he was uncertain as to whether a readvance or retreat was occurring in that year. Although the post-1907 shrinkage does not date the onset of Fan Mountain glaciation, the fresh surface appearance of the Fan Mountain moraines seems to be little, if at all, different from currently forming morainal deposits. The writer feels that it is quite possible that the Fan Mountain advance of the Okpilak Glacier occurred in recent historic time.

All glaciers observed in the Romanzof Mountains that are comparable in size to the Okpilak Glacier show evidences of recent retreat and thinning similar to those described above. Present termini of glaciers have commonly withdrawn several hundred feet leaving unweathered, unstable terminal moraines, till ridges, or formless drift at many localities. The writer believes that the shrinkage of these glaciers coincided with that of the Okpilak Glacier. It seems likely that climatic conditions leading to a general shrinkage of valley glaciers in the Romanzof Mountains and perhaps in the entire 
Brooks Range have occurred during the last half of the 19th and the first half of the 20th century.

Other workers in the Brooks Range (Holmes and Lewis 1960), in northern Ellesmere Island (Hattersley-Smith 1960), and in northeast Greenland (Krinsley 1960) recognize recent advance and recent or present recession in their respective areas.

\section{References}

Detterman, R. L. 1953. in Péwé et al. Multiple glaciation in Alaska. U. S. Geol. Surv. Circ. 289, pp. 11-12.

Detterman, R. L., A. L. Bowsher, and J. T. Dutro, Jr. 1958. Glaciation on the Arctic Slope of the Brooks Range, northern Alaska. Arctic 11:43-61.

Hattersley-Smith, G. 1960. Some glaciological studies in the Lake Hazen Region of northern Ellesmere Island. Abstr. in Program, First International Symposium on Arctic Geology. Reprinted from Can. Oil Gas Ind., December 1959.

Holmes, G. W., and C. R. Lewis. 1960. Glacial geology of the Mt. Chamberlain area, Brooks Range, Alaska. Abstr. in Program, First International Symposium on Arctic Geology. Reprinted from Can. Oil Gas Ind., December 1959.

Keeler, C. M. 1959. Notes on the geology of the McCall Valley area. Arctic 12:87-97.

Krinsley, D. B. 1960. Late Pleistocene glaciation in northeast Greenland. Abstr. in Program, First International Symposium on Arctic Geology. Reprinted from Can. Oil Gas Ind., December 1959.

Kunkle, G. R. 1958. Multiple glaciation in the Jago River area, northeastern Alaska. Univ. of Michigan Master's thesis, pp. 1-41, unpubl.

Leffingwell, E. de K. 1919. The geology of the Canning River region, Alaska. U. S. Geol. Surv. Prof. Pap. 109:1-251.

Sater, J. E. 1959. Glacier studies of the McCall Glacier, Alaska. Arctic 12:82-6. 